\title{
Historical perspectives of The American Association for Thoracic Surgery: Lyman A. Brewer III (1907-1988)
}

\author{
James I. Fann, MD
}

Lyman A. Brewer III, the 54th president of The American Association for Thoracic Surgery (AATS), was born in Toledo, Ohio, on July 28, 1907 (Figure 1). Brewer's father, an engineer and innovative businessman, was the first to import seamless steel tubes into this country. ${ }^{1}$ Notably, Brewer's grandfather, Lyman A. Brewer, was a Civil War surgeon, and his uncle Lyman A. Brewer II was Professor of Surgery at the Toledo Medical College. Recognizing his family's surgical legacy, Brewer chose medicine as his calling, although his engineering inventiveness was to be later evident. He attended Scott High School and matriculated in 1924 at Amherst College, an environment that nurtured his lifelong interest in history, literature, and the humanities. ${ }^{1,2}$ After graduation from college in 1928, Brewer attended University of Michigan Medical School, obtaining his doctorate in medicine in 1932. He, along with his friend Paul C. Samson, the 48th AATS president, continued postgraduate study for 6 months in the department of pathology. Known as the "Toledo Terrors," they were to cross paths many times as the 2 became future leaders of thoracic surgery. ${ }^{1-3}$ Brewer then trained for 6 months in surgery in Toledo, followed by 18 months in internal medicine at Boston City Hospital and 12 months each of treating thoracic disease and of surgery at Bellevue Hospital in New York. ${ }^{2}$

The 1920s and 1930s marked a new epoch in thoracic surgery. John Alexander, the 17th AATS president, popularized anterior thoracoplasty and resection of the transverse processes of the vertebrae in treating tuberculosis. ${ }^{4}$ Pulmonary resection for infection and cancer was realized by Howard Lilienthal, the 5th AATS president, and Harold Brunn, the 21th AATS president, the latter of whom reported a series of patients undergoing single-stage lobectomy (5 for bronchiectasis and 1 for malignancy). ${ }^{5}$ In 1933, Evarts Graham, the 10th AATS president, performed the first successful single-stage pneumonectomy for lung cancer. ${ }^{6}$ Considered infrequent in the early 1900s, the increased incidence and diagnosis of lung cancer in the 1930s and the surgical approach to this disease were to change forever the thoracic surgical landscape. ${ }^{7}$ In view of these

From the Department of Cardiothoracic Surgery, Stanford University, Stanford, Calif. Received for publication June 1, 2011; accepted for publication June 28, 2011; available ahead of print Aug 8, 2011.

Address for reprints: James I. Fann, MD, Department of Cardiothoracic Surgery, Stanford University, 300 Pasteur Dr, Stanford, CA 94305 (E-mail: jfann@stanford.edu).

J Thorac Cardiovasc Surg 2012;143:1244-6

0022-5223/\$0.00

Published by Elsevier Inc. on behalf of The American Association for Thoracic Surgery

doi:10.1016/j.jtcvs.2011.06.035

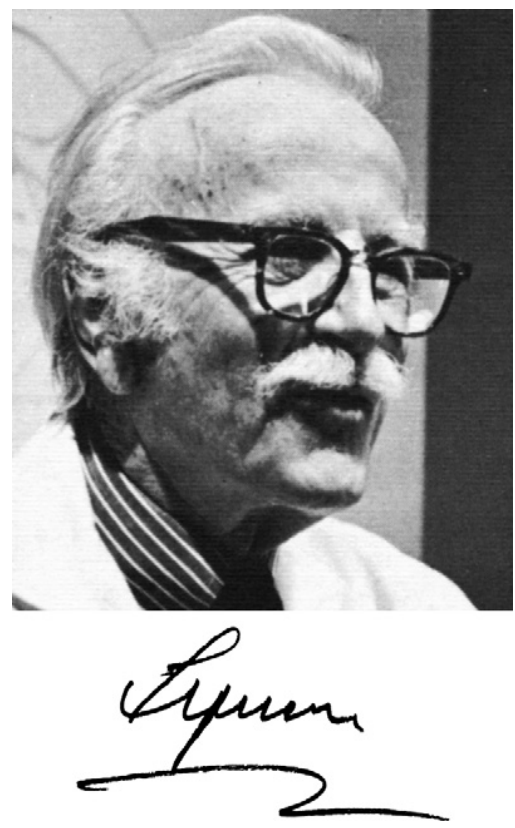

FIGURE 1. Photograph of Lyman A. Brewer III and his signature.

momentous achievements and with his keen interest in chest disorders, Brewer trained with Graham at Washington University in St Louis for 18 months and later with Alexander at the University of Michigan for his final year of training. ${ }^{1,2}$

After completing training in 1941, Brewer entered practice in Los Angeles as one of the first full-time thoracic surgeons on the West Coast with another Graham trainee Frank S. Dolley, the 24th AATS president. ${ }^{1,2}$ Not long thereafter, in September 1942, Brewer enlisted in the Army Medical Corps and served in the Second Auxiliary Surgical Group in both Mediterranean and European theaters during World War II. Working under the direction of Colonel Edward Churchill, the 28th AATS president, and partnering with 2 other young thoracic surgeons, namely his old friends Samson and Thomas H. Burford, the 51st AATS president, Brewer initiated a review of thoracic casualties in the Mediterranean theater and affirmed the need to establish thoracic surgery as a distinct specialty. ${ }^{1-3}$ As he recalled ${ }^{3}$ :

We gave battle to the Mediterranean Theater of Operations Medical Administration in North Africa on July 19, 1943, to gain permission to establish the first Base Station Chest Center in the USAMC overseas at the 53rd Station Hospital. Working in tents on a bleak desert plain in northern Tunisia, we proved to the doubting medical administrative hierarchy that well-trained thoracic surgeons could 
significantly lower the mortality for chest wounds in a base section hospital. The success in the perfection of the operation of pulmonary decortications, the introduction of penicillin for gram-positive organisms, and the removal of intrathoracic foreign bodies convinced the military "brass" that the time was at hand to take thoracic surgery out of the swamp of "septic surgery" where it had stagnated for so many years.

The contributions of the Second Auxiliary Surgical Group in patient care and research and the development of thoracic surgery under the difficult battlefield conditions of a field hospital (now known as Mobile Army Surgical Hospital, or MASH) remain major highlights in the history of military medicine. ${ }^{8}$ New surgical techniques, which proved of value in subsequent wars, and criteria for emergency thoracotomy and management of thoracic and thoracoabdominal injuries were developed and standardized. ${ }^{1,9}$ In his classic article, "The Wet Lung in War Casualties," Brewer noted the following ${ }^{10}$ :

We are impressed more and more as time goes on with the important role that anoxia plays in increasing the degree of shock in acutely injured patients. The therapeutic measures advocated, in the main, are those which improve the respiratory airway and provide adequate oxygen supply to the pulmonary capillaries, even though it means "forcing" the oxygen into the alveoli under mild positive pressure. In our experience in the Forward Hospitals, edema of the lungs appeared to be the most significant finding at autopsy in patients who survived the initial shock but later died of their chest injury.

That article was the first report of increased fluid content in the lung as the result of severe trauma to the brain, abdomen and extremities, as well as to the chest. ${ }^{8}$ Later defined during the Vietnam War as "adult respiratory distress syndrome," this injury remains a common cause of death in the intensive care unit.

Retired from active service as Lieutenant Colonel in 1945, Brewer returned to Los Angeles to resume his thoracic surgical practice. Central to his professional career was teaching medical students, interns, and residents; he often scheduled his private practice commitments around lectures and surgical conferences. ${ }^{1,2}$ Teaching for more than 4 decades, he held academic appointments as Professor of Surgery at Loma Linda University and University of California, Irvine, and served as Professor and Chairman of Surgery at University of Southern California from 1953 to $1956 .^{2}$

In the 1940s, the innovative Brewer developed techniques and medical equipment for the treatment of patients with trauma. He was the first to use positive-pressure breathing in the clinical setting to combat pulmonary edema. ${ }^{1,2}$ While working with V. Ray Bennett at the Los Angeles County General Hospital, he helped to develop the early Bennett ventilator, the forerunner of the volumeand pressure-regulated ventilator used today to treat pulmonary edema and insufficiency. ${ }^{1,2}$ In the following decade, his group worked on modifying the pump oxygenator for heart surgery. Reflecting on the early engineering and logistical challenges, he recalled ${ }^{11}$ :

Although the Gibbonses [John H Gibbons, Jr, the 40th AATS president, and Mary Hopkins Gibbons] had shown that a pump oxygenator was feasible, their machine was not available, so each team in the 1950s in this country had to work out its own program....After a year's effort [with the Dewall oxygenator], during which time we did not have consistent results, we switched to the Kay-Cross disc-type oxygenator. This device was modified in a machine shop by our resident, Wilfred Huse, with the construction of an infant-sized and a large adult-sized cylinder-disc oxygenator to fit the largest and the smallest patients....On October 13, 1958, we successfully closed multiple ventricular septal defects in a case with a classic pentology of Fallot.

In 1943, after entering military service, Brewer married Jane Lippett, an extremely supportive and gifted life companion. $^{1,2}$ They raised 3 sons, Daniel, Lyman IV, and Jonathan, and were blessed with many grandchildren. After a courageous battle with lymphoma, Brewer died at the age of 80 on June 25, 1988. Several years before his death, Brewer and his wife established the Lyman Brewer III Charitable Foundation, which became a part of the White Memorial Medical Center in Los Angeles. ${ }^{1}$ One mission of the foundation was to provide scholarships for indigent students of East Los Angeles to study nursing and allied health sciences. The foundation's board, directed by Mrs Brewer, supported the community through the Visiting Parish Nurse Program to assist the ill and bereaved after tragedies, such as gang warfare. ${ }^{1}$ Mrs Brewer died at the age of 91 on May 10, 2007.

Brewer was a prolific contributor to the scientific literature, publishing 7 books and more than 100 articles spanning a broad spectrum of cardiothoracic surgical topics, including surgical and medical treatment of tuberculosis, traumatic wounds of the chest and heart, lung cancer, esophageal disorders and carcinoma, cardiopulmonary bypass, mitral valve surgery, the use of pericardial fat to buttress the bronchial stump, and cardiac transplantation. After V-E Day in Europe, Brewer, Paul Kennedy, Gordon Madding, and Samson wrote Forward Surgery of the Severely Wounded, which at 931 pages was probably the most comprehensive review of the management of more than 10,000 casualties treated by a single 
military unit. ${ }^{12}$ Additionally, with Burford, Brewer contributed to 2 volumes on thoracic surgery in the series Surgery in World War II, published by the Army Medical Department in 1963. ${ }^{1,13}$ A devoted student of surgical history, he documented events such as the impact of the first pneumonectomy and the histories of esophageal surgery and of sphygmology. He profiled notable figures in surgery, including Carrel and Larrey, and thoughtfully recorded his reflections in memory of his friends Samson and Burford. ${ }^{3,14}$

Brewer was the recipient of many honors, including serving as president of not only the AATS but also the Society of Thoracic Surgeons and the Pacific Coast Surgical Association. He was the governor and vice president of the American College of Surgeons and a founding member of the American Board of Thoracic Surgery. In 1975, a cardiothoracic symposium founded by his former trainee Louis G. Ludington evolved into the Lyman A. Brewer III International Surgical Society, consisting of an annual meeting focused on a topic in cardiothoracic surgery. ${ }^{1,2}$ Believing that medicine transcended international boundaries, Brewer directed the Society's first symposium abroad to be held in Beijing in 1981; this successful meeting was the first international cardiothoracic surgery symposium held in China since the Cultural Revolution in 1959. ${ }^{1,2}$ His impact on education continues to this day at the Annual Meeting of the Western Thoracic Surgical Association, where the Brewer Postgraduate Course highlights innovative developments in cardiothoracic surgery.

In his presidential address at the 54th annual meeting of the AATS in 1974, Brewer discussed the heritage of the AATS founders and the challenges facing the practice of thoracic surgery. ${ }^{9}$ To improve the practice of thoracic surgery, he presciently described the need to obtain physician practice information to impact government legislation, to coordinate activity among thoracic surgery organizations, to assist newly trained thoracic surgeons to find employment, to evaluate the certification and recertification process, to be concerned about the rising cost of health care, to consider concentrating thoracic surgical services in specialized centers, and, importantly, to have "an increased social consciousness to make certain that we have adequate delivery of thoracic surgical care." ${ }^{9} \mathrm{He}$ concluded as follows ${ }^{9}$ :

Now that open thoracotomies, closed and open-heart surgery, and organ transplantation are a reality, we must not become "fat burghers" and rest on our laurels. Cancer, heart diseases, congenital malformations, and infections remain as clinical challenges. To these we must add the social challenges of the 1970s. The hallmark of the thoracic surgeon is his inventiveness and hard work. Let us use this same drive and resiliency in devising better types of treatment and better ways of delivery.

Possessing a profound knowledge of history, arts and literature, Brewer nurtured a strong social conscience and deep respect and feeling for his colleagues and patients. ${ }^{1,2}$ In reviewing Brewer's life's work, his friend and colleague Richard Carter summarized it best: "Brewer was a surgeon extraordinaire, a unique amalgam of intelligence and integrity, optimism and charm, with an insatiable zest for life and a marvelous sense of humor." 1

I thank Dr John E. Connolly at the University of California, Irvine, for his invaluable assistance in preparing this profile.

\section{References}

1. Carter R. Lyman A. Brewer III (1907-1988): surgeon-scientist, inspirational teacher, and humanist. Ann Thorac Surg. 1998;65:2132-4.

2. Peters RM. Lyman A. Brewer, III, 1907-1988. Ann Thorac Surg. 1988;46:485-6.

3. Brewer LA 3rd. In memoriam: Paul C. Samson. Am J Surg. 1982;144:165.

4. Sloan H. Historical perspectives of the American Association for Thoracic Surgery: John Alexander (1891-1954). J Thorac Cardiovasc Surg. 2005;129:435-6.

5. Brunn H. Surgical principles underlying one-stage lobectomy. Arch Surg. 1929; 18:490-515.

6. Graham EA, Singer JJ. Successful removal of an entire lung for carcinoma of the bronchus. JAMA. 1933;101:1371-4.

7. Horn L, Johnson DH. Evarts A. Graham and the first pneumonectomy for lung cancer. J Clin Oncol. 2008;26:3268-75.

8. Brewer LA III. The contributions of the Second Auxiliary Surgical Group to military surgery during World War II with special reference to thoracic surgery. Ann Surg. 1983;197:318-26.

9. Brewer LA III. Presidential address: A heritage and a challenge. J Thorac Cardiovasc Surg. 1974;68:177-88.

10. Brewer LA III, Burbank B, Samson PC, Schiff CA. The "wet lung" in war casualties. Ann Surg. 1946;123:343-62.

11. Brewer LA III. Open heart surgery and myocardial revascularization. Historical notes. Am J Surg. 1981;141:618-31.

12. Kennedy P, The Second Auxiliary Surgical Group. In: Brewer LA III, ed. The early history and era of development of the Pacific Coast Surgical Association. Chicago: The Pacific Coast Surgical Association; 1982. p. 193-202.

13. Coates JB Jr, Berry FB, McFetridge EM. Medical Department, United States Army Surgery in World War II: thoracic surgery, volumes 1 and 2 [Internet]. Washington: Office of the Surgeon General, Department of the Army; 1963 [cited]. Available from: http://history.amedd.army.mil/booksdocs/wwii/thoracic surgeryvolI/default.htm/ and http://history.amedd.army.mil/booksdocs/wwii/ thoracicsurgeryvolii/default.htm/. Accessed July 212011.

14. Brewer LA III. Thomas Hannahan Burford, 1908-1977. Ann Thorac Surg. 1978; $25: 1-2$. 